\title{
Frederick Banting (1891-1941): Discoverer of insulin
}

\author{
Siang Yong $\underline{\operatorname{Tan}}^{1}$, MD, JD, Jason Merchant $^{2}$, MD
}

I am a firm believer in the theory that you can do or be anything that you wish in this world, within reason, if you are prepared to make the sacrifices, think and work hard enough and long enough. - Frederick Banting

$\mathrm{T}$ he Greeks first used the term 'diabetes', with the meaning 'to pass through', to denote the large amount of water consumed and urine produced in diabetics. The Romans added the term 'mellitus', meaning 'sweet as honey', when they noticed that the urine of diabetics was sweet. In the not-too-remote past, the prognosis for children with this affliction was very poormost survived no more than a year past their diagnosis. In adults, less than 20 per cent of diabetic patients lived past ten years. Sir Frederick Banting, a physician and scientist, was the co-discoverer of insulin, a hormone of critical importance in regulating blood sugar levels. When insulin action is deficient, one develops diabetes mellitus. Due to Banting's discovery of insulin, millions of people worldwide were able to extend their lives by decades. In 1923, Banting became the first Canadian and the youngest person, at age 32 , to receive the Nobel Prize in Physiology/Medicine.

EARLY LIFE LESSONS Banting was born on a farm in Ontario, Canada, on 14 November 1891. Two childhood experiences led him to choose a career in medicine. The first was the collapse of a roof that two men were working on. Banting quickly ran to get the town doctor, whose presence calmed the chaotic scene. The second involved

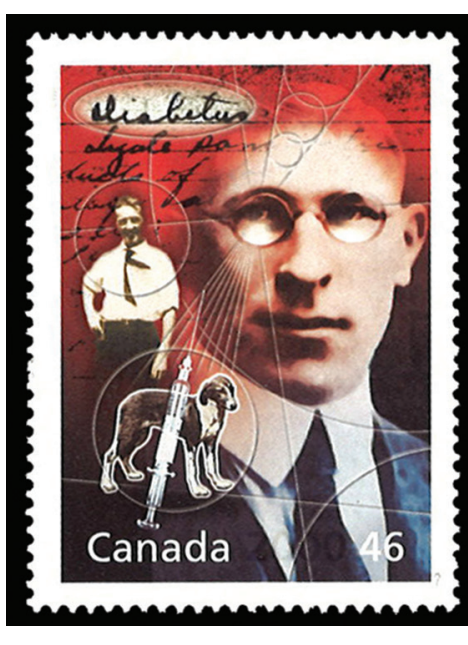

Ontario as a professor. One of his lectures was on the pancreas and, as part of his preparation, Banting meticulously reviewed all known information about the gland. It was well known that the pancreas produced various juices that flowed through tubes into the intestine to help break down food. Yet, experiments by Dr Joseph Freiherr von Mering and Dr Oscar Minkowski in 1890 showed that pancreatectomised dogs also exhibited many of the features of human diabetics. In 1900, Dr Eugene Lindsay Opie commented that the pancreas of diabetics would appear normal except for shrivelled clusters of cells named islets of Langerhans. A report by Dr Moses Barron described an autopsy done on a patient whose pancreatic duct had been obstructed by pancreatic stones. The acinar cells in the gland had been destroyed, but the islet cells were preserved. This was similar to experiments done in 1901 by Dr Leonid Ssobolew, in which the islet cells of dogs remained viable even after the pancreatic ducts had been ligated. On the night before his lecture, Banting was mulling over this information just before going to sleep. He scribbled in his notebook: "Diabetus [sic]. Ligate pancreatic ducts of dog. Keep dogs alive till acini degenerate leaving islets. Try to isolate the internal secretion of these to relieve glycosurea [sic]."

\section{FROM THOUGHT TO FRUITION}

In previous experiments, the extract from a healthy pancreas had been given to diabetics with no improvement. Banting proposed that the next step was to develop a purified extract from only the islet cells. He approached Professor John James Rickard Macleod, an one of his closest friends, Jane. She was bright and energetic until 14 years of age, when she started to lose weight and complained of an unquenchable thirst. Jane passed away a few months later from diabetes mellitus, and Banting was one of her pallbearers. Feeling the pain of such a pointless death, he wondered how no doctor had found a cure for such a terrible disease.

NEW BEGINNINGS Although Banting's desire to become a doctor initially conflicted with his family's wishes, he was eventually able to transfer from his theology college to the University of Toronto Medical School in Toronto, Canada. World War I briefly interrupted his education, as he enlisted in the Canadian army, serving with an ambulance corps in France. When the war was over, Banting returned to complete his training as an orthopaedic surgeon at The Hospital for Sick Children in Toronto, then opened an office in London, Ontario, Canada. As business was slow, he worked part-time at the University of Western expert in carbohydrate metabolism who headed a large laboratory at the University of Toronto. Professor Macleod was initially unimpressed with Banting's theory, but eventually allowed him the use of the laboratory. In May 1921, Banting started the experiment with the help of Dr Charles Herbert Best, a 21-yearold medical student. They first tied off the pancreatic ducts of dogs; after several weeks, they removed the atrophied pancreas and created an extract, which they injected into the vein of a sickly dog named Marjorie, whose pancreas had been removed several days earlier. After an hour, there was a noted change in the dog's demeanour. It was able to raise its head, stand and even wag its tail. There was a dramatic decrease in the dog's blood sugar levels. Since the extract of islet cells was the cause of this reversal, Banting named it 'isletin'.

However, this success was short-lived, as the drop in blood sugar was temporary. Banting realised that he needed a larger source of pancreas extract, and soon became aware of a new 
report describing how the pancreas of fetal and newborn animals had a higher proportion of islet cells than an adult pancreas. Familiar with farm activities from his childhood days, Banting knew that farmers impregnated cows to increase their weight for the market. At the time of slaughter, they would discard the embryos, which he was able to procure. To his delight, cow isletin worked just as well as the extract made from dogs. When Professor Macleod returned from Scotland, he questioned the data and demanded additional experiments. Banting took these criticisms as a personal rebuke and threatened to leave for the United States to finish his work. Faculty members at the university were able to persuade Banting to stay, although the relationship between the two would remain forever strained.

As the experiments continued, Professor Macleod realised the importance of their discovery and soon devoted his entire lab to the project. He also decided to change the name of the material to 'insulin', Latin for 'island'. With the help of a biochemist, Dr James Collip, the team was eventually able to purify insulin for human use.

\section{AWARDS, ACCOLADES AND ANIMOSITY}

The exact details of how much Professor Macleod contributed to the research has become an area of contentious debate. According to Banting's recollection, Professor Macleod had no part in the initial experiments and did not become involved until after he returned from Scotland. Professor Macleod countered this claim, stating that he guided Banting and Dr Best from the very beginning. However, it was widely known that there was great hostility between the two men, as Banting felt that Professor Macleod was taking more of the credit than he deserved. This bitterness came to a head in 1923, when they were both awarded the Nobel Prize for the discovery of insulin. Banting was irate that Professor Macleod was to be awarded the prize while Dr Best was not mentioned, and initially refused the honour. Although he was eventually persuaded to change his mind, Banting also decided to publically credit Dr Best and share half of his prize money with him. Not to be outdone, Professor Macleod acknowledged Dr Collip's contribution to the project and shared his prize money with him.
AN EARLY DEATH AT 49 Banting loved painting, which helped him to escape from the constant pressure that the world of medicine placed on him. He used the alias 'Frederick Grant' in his works of art. In 1927, he met AY Jackson, a landscape painter belonging to the Group of Seven, a group of Canadian artists. The two quickly became friends, and Banting frequently travelled with these artists to remote areas of the world for inspiration. When questioned by Jackson about possibly painting full-time, Banting responded: "When I am fifty, that's what I intend to do."

When World War II broke out, Banting again served in the Canadian military, this time as coordinating chairman of medical research, focusing on aviation medicine as well as biological warfare. On 20 February 1941, he took a transatlantic flight to England to consult with his British counterparts about his new research. Shortly after the plane took off from Newfoundland in Canada, one of its engines failed. While returning to base, the other engine failed as well. The pilot brought the plane down in the darkness and came within a few feet from a safe landing on a frozen lake, but a wing clipped a large tree at the last moment. Banting sustained severe head wounds and a broken left arm. By the time search planes spotted the crash site four days later, he had succumbed to his injuries. Banting died at the age of 49 .

\section{BIBLIOGRAPHY}

- Banting FG, Best $\mathrm{CH}$. The internal secretion of the pancreas. J Lab Clin Med 1922; 7:251-66.

- Berger M. Famous Men of Modern Biology. New York: Thomas Y Crowell Co, 1968.

- Canadian Diabetes Association. Frederick Grant, Artist [online]. Available at: http://www.diabetes.ca/about-cda/banting-house/frederick-grant-artist. Accessed June 4, 2008.

- Harris S. Banting's Miracle: The Story of the Discovery of Insulin. Philadelphia: J B Lippincott Co, 1946.

- MacLeod JB. Frederick G. Banting: giving prospects for life from the past to the new millennium. Arch Surg 2006; 141:705-7.

- Nobelprize.org. Frederick G. Banting - Biographical [online]. Available at: http://nobelprize.org/nobel_prizes/medicine/laureates/1923/banting-bio. html. Accessed June 4, 2008.

- Rosenfeld L. Insulin: discovery and controversy. Clin Chem 2002; 48:227088. 